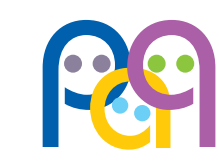

Published in Internet: 18-june-2015

Marta Ibáñez Tortajada: marta_690@hotmail.com

\section{Effects of breastfeeding on quality of life and the development of atopic dermatitis}

\author{
M. Ibáñez Tortajada ${ }^{a}$ J. V. Sorli Guerolab
}

${ }^{a}$ CS de Atención Primaria de Alaquás, Valencia. España • bDepartamento de Medicina Preventiva y Salud Pública. Universitat de València. CIBER Fisiopatología de la Obesidad y Nutrición. Valencia. España.
Key words:

- Atopic dermatitis

- Breastfeeding

- Life's quality
Introduction: atopic dermatitis (AD) is a disease of increasing prevalence and of great social impact. Its etiology has a multifactorial origin, so we analyze if environmental factors, especially breastfeeding (BF) is involved in the development of $A D$. The objectives are to assess the clinical severity and quality of life of children with $A D$, to detect differences in the age of diagnosis according to the type of lactation received, and to estimate the association of atopic dermatitis to the variables of interest analyzed.

Material and methods: case-control study matched by age and sex in children in Primary Care. It has been done by filling in three different questionnaires about children who come to their routine health controls established by the Valencian Community Health Service. The data collected will be analyzed with the program SPSS.

Results: atopic dermatitis has an earlier diagnosis in baby boys. A protective effect of breastfeeding vs artificial feeding in the development of AD (OR: 0.15; IC 95\%: 0.09-0.24) has been observed, also vs allergy to pollen or allergic rhinitis (OR: 0.35; IC 95\%: 0.17-0.73), vs dry skin (OR: 0.22; IC 95\%: 0.14 0.36 ), itching (OR: 0.50; IC 95\%: 0.27-0.93) and in parallel to the clinical characteristics and impact on quality of life (questionnaire score ICVDAI: $2.3 \pm 3.5$ vs $0.7 \pm 0.1 ; p<0.001$ ).

Conclusion: the choice of breastfeeding improves the quality of life in children, protects against the onset of atopic dermatitis, allergy to pollen or allergic rhinitis, and against some skin clinical features.

\title{
Efecto de la lactancia materna en la calidad de vida y en el desarrollo de la dermatitis atópica
}

Palabras clave:

- Dermatitis atópica

- Lactancia materna

- Calidad de vida

Introducción: la dermatitis atópica (DA) es una patología de prevalencia creciente y de gran repercusión social. Siendo su etiología de origen multifactorial, analizamos si factores ambientales, especialmente la lactancia materna (LM), intervienen en su desarrollo y evolución. Los objetivos son evaluar la gravedad clínica y la calidad de vida de los niños con DA, detectar diferencias en la edad de diagnóstico según el tipo de lactancia recibida y estimar la asociación de padecer DA según las variables de interés analizadas.

Material y métodos: estudio de casos y controles apareado por edad y sexo en población infantil de Atención Primaria. Se realiza mediante el cumplimiento de tres cuestionarios a niños que acuden a las revisiones de salud establecidas por la Consellería de Sanidad de Valencia. Los datos recogidos se analizarán con el programa SPSS ${ }^{\circledR}$.

Resultados: la DA se presenta más precozmente en los varones. Se observó un efecto protector de la $L M$ frente a la lactancia artificial (LA) sobre el desarrollo de la DA (odds ratio [OR]: 0,15; intervalo de confianza del 95\% [IC 95\%]: 0,09-0,24), frente a procesos de alergia al polen o rinitis alérgica (OR: 0,35; IC 95\%: 0,17-0,73), frente a la piel seca (OR: 0,22; IC 95\%: 0,14-0,36), al picor (OR: 0,50; IC $95 \%: 0,27-0,93)$ y paralelamente en la repercusión de características clínicas y en la calidad de vida (puntuación del cuestionario Índice de Calidad de Vida de la Dermatitis Atópica Infantil [ICVDAI]: $2,3 \pm 3,5$ frente a $0,7 \pm 0,1 ; p<0,001$ )

Conclusión: la elección de la LM mejora la calidad de vida en los niños, protege frente a la aparición de DA, de alergia al polen o rinitis alérgica y frente a algunas características clínicas cutáneas.

How to quote this article: Ibáñez Tortajada M, Sorlí Guerola JV. Efecto de la lactancia materna en la calidad de vida y en el desarrollo de la dermatitis atópica. Rev Pediatr Aten Primaria. 2015;17:115-24. 


\section{INTRODUCTION}

Atopic dermatitis (AD) may be defined as an inflammatory disorder of the skin that first develops in childhood and characterised by lesions of specific morphology and distribution with a chronic and recurring course, and it usually occurs in children with a personal or family history of atopy (the "atopic triad": asthma, rhinoconjunctivitis and $A D) .{ }^{1}$ Defining $A D$ is challenging due to the broad variability in the morphology and location of its lesions, and in the changes that occur in each patient over the course of disease. Despite the numerous studies performed in the past 40 years, research has not identified a biomarker that can be used to detect the disease, so its diagnosis is based on clinical features. ${ }^{2}$

The data on the actual incidence and prevalence of $A D$ are variable and even contradictory because diagnostic and assessment criteria have not been standardised. Atopy affects between 5\% and 15\% of the general population. As for the age of onset, it usually appears before 5 years in $80 \%$ to $90 \%$ of the patients, and onset occurs most frequently in the first year of life ( $60 \%$ of the cases). ${ }^{3}$

The prevalence of AD has been increasing in the past 30 years and all epidemiological studies agree that it is higher (as occurs in all allergic diseases) in cities and industrialised areas than in rural areas. In recent decades, most of the research on AD has focused on studying the aetiopathogenic mechanisms of the disease, but for now we have not identified any diagnostic or prognostic markers applicable to clinical practise, ${ }^{4,5}$ nor factors with a demonstrated association with the impact of $A D$ on the quality of life of affected children. ${ }^{6}$

Breastfeeding (BF) is the preferred feeding method in infancy due to its nutritional, immunological and psychological benefits. ${ }^{7}$ Since Grulee and Sanford found that $A D$ was seven times less frequent in children that were breastfed in 1936, the controversy on the role of $\mathrm{BF}$ in the prevention of allergic diseases has only increased. ${ }^{8,9}$ There are several reasons for this: on one hand, there is the immunological complexity of breast milk and the genetic differences between mother and child; on the other, the methodological differences in the studies that either support or dispute the protective and sensitizing qualities of breast milk. ${ }^{10}$

In short, there is evidence that exclusive BF or mixed feeding with hydrolysed formula for at least 4 months in children at high risk of developing AD decreases the incidence of AD and cow's milk protein allergy in the early years of life. ${ }^{9,11}$ The evidence is weaker for infants that are not at risk of developing atopy. Breastfeeding beyond 4 months of age does not seem to provide greater benefits or have an impact on the incidence of $A D$, although some studies suggest a protective effect of BF against $A D$ and asthma. ${ }^{7,12,13}$

The goals of our study were to analyse the relationship of $B F$ and the development of $A D$, assess the clinical severity and quality of life of children with $A D$, detect differences in the age at diagnosis depending on feeding modality, and estimate the correlation between developing $A D$ and the variables under study.

\section{MATERIALS AND METHODS}

We conducted an age- and sex-matched case-control study in the paediatric population of an urban health care centre located in the metropolitan area of Valencia (Spain), in children that attended "Child health programme" check-ups ranging from the first newborn visit through age 14 years, in order to identify risk factors in children suffering from $A D$ and analyse their quality of life in relation to the impact of breastfeeding.

We calculated the sample size taking into account the prevalence of $A D$ and the exposure frequency in previous studies, ${ }^{2,14,15}$ assuming a target population of 5088 children, selecting two controls for each case, and setting the alpha error level at 0.05, which resulted in an estimated minimum sample size of 390 individuals ( 130 cases and 260 controls). We defined feeding modalities adhering to international recommendations. ${ }^{16}$ Children were classified as cases of AD when they met the diagnostic 
criteria established by Hanifin and Rajka $(1980)^{17}$, and if the patient scored above the established cut-off point in the questionnaire and/or gave answers that led to suspecting the disease, the individual results were discussed with the paediatrician and the patient continued to be evaluated for a potential diagnosis and to ultimately determine the presence or absence of the disease. Patients were selected at random. The study was approved by the Ethics Committee and we requested the informed consent of the parents or legal guardians of all children, and had them fill out the various questionnaires. We included 420 individuals (140 cases, 63 girls and 77 boys; 280 controls, 126 girls and 154 boys).

Three questionnaires were administered. We collected data on clinical, socioeconomic and environmental variables, feeding modality and food reactions for all patients. The Scoring Atopic Dermatitis $(\mathrm{SCORAD})^{18}$ questionnaire was administered in cases of $A D$ to quantify disease severity, while asking the age at diagnosis, the body surface area affected, and the seasonal pattern of clinical manifestations, ${ }^{20}$ while quality of life in children with $A D$ was assessed by means of the Indice de Calidad de Vida de la Dermatitis Atópica Infantil (Childhood Atopic Dermatitis Quality of Life Index [ICVDAI]) ${ }^{19}$ scale.

We entered the data collected in the questionnaires in a database built for that purpose and analysed them with the SPSS ${ }^{\oplus}$ software version 19.0 using standard statistical methods.

\section{RESULTS}

The descriptive characteristics are summarised in Table 1. We found no significant differences between cases and controls based on age and sex. Figure 1 shows the changing distribution of feeding modalities. Since the mixed feeding group was small, it was combined with the BF group in the statistical analyses. We did not find statistically significant differences in the choice of feeding modality or the duration of BF as a function of socioeconomic status. We also found no differences in the choice of feeding modality or the duration of BF based on parental level of education.

Breastfeeding was more frequent in the control group (Figure 2), but we did not observe significant differences in the duration of $B F$, which was $7.1 \pm 6.9$ months in the cases and $7.6 \pm 7.5$ months in the controls $(P=.609)$. When we calculated the risk of being a case based on having been breastfed we observed a clear protective effect (odds ratio [OR], 0.30; 95\% confidence interval [95\% Cl], 0.21-0.44; $P<.001)$, even after adjusting for age, sex and family history (OR, 0.15; 95\% Cl, 0.09-0.24; $P<.001)$.

The most important reasons reported for choosing artificial feeding (AF) included difficulties in latching on in $9.5 \%$, followed by hypogalactia in $8.6 \%$, a past negative experience with BF and work-related problems for mothers in $6.7 \%$, various reasons in $30.4 \%$, and no particular reason for the choice in $44.8 \%$. Meanwhile, the reported reasons for choosing mixed feeding were the absence of let-down (if

\begin{tabular}{|l|c|c|c|c|}
\hline \multicolumn{2}{|l|}{ Table 1. Descriptive characteristics of the sample } & Female & Total & $P$ \\
\hline N (\%) & Male & $189(45 \%)$ & 420 & .001 \\
\hline Mean age (years) & $231(55 \%)$ & $5.5 \pm 3.2$ & $4.9 \pm 3.1$ & .513 \\
\hline AD diagnosis & $4.5 \pm 2.9$ & $63(45 \%)$ & $140(100 \%)$ & .046 \\
\hline Mean age at diagnosis (years) & $77(55 \%)$ & $1.5 \pm 2.2$ & $1.1 \pm 1.7$ & \\
\hline Type of feeding received (\%) & $0.9 \pm 1.1$ & & 70 & .243 \\
Breastfeeding & & 3.7 & 5 & \\
Mixed feeding & 66.8 & 22.3 & 25 & .945 \\
Artificial feeding & 6.0 & $7.3 \pm 6.7$ & $7.4 \pm 7.2$ & \\
\hline Breastfeeding duration (months) & $7.4 \pm 7.7$ & 27.2 & & \\
\hline
\end{tabular}

AD: atopic dermatitis. 


\section{Figure 1. Evolution in the distribution of feeding modalities}

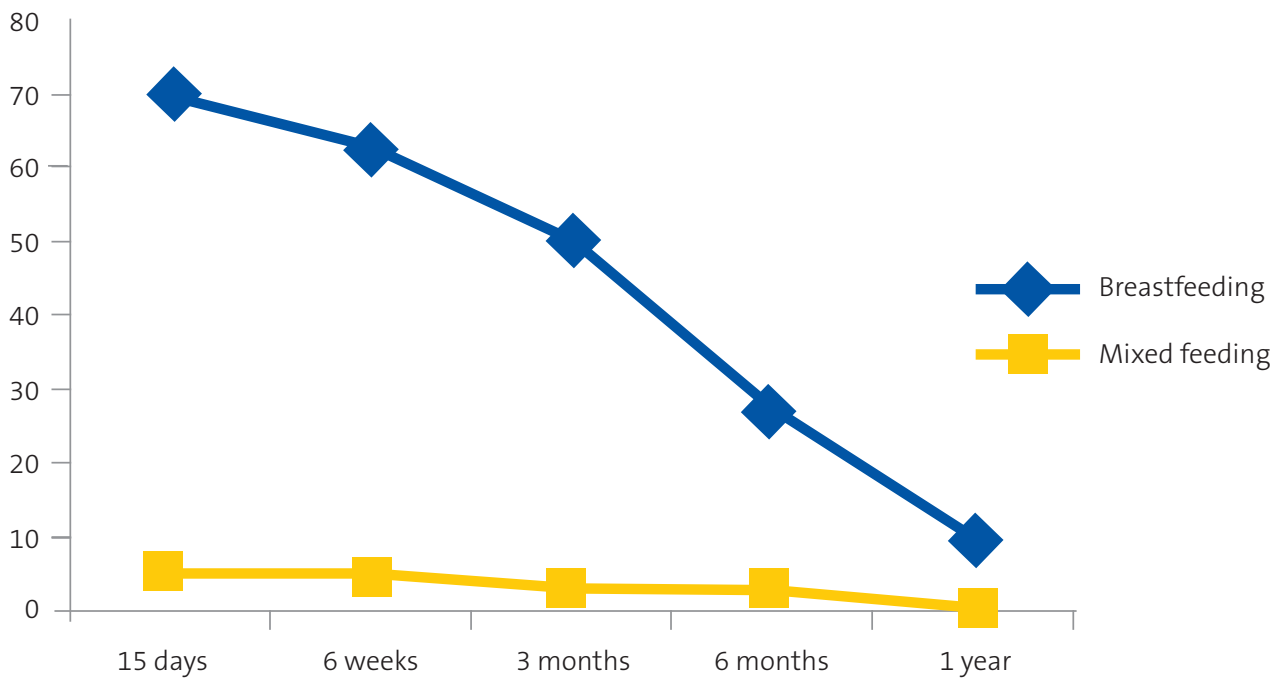

there is no let-down, there is no milk, this probably The mean body surface area affected in AD cases corresponded to hypogalactia or a low milk supply) measured by the SCORAD index was of $27.8 \pm 27.3$ in $66.7 \%$, while $19.0 \%$ reported that "the child was points overall, with a mean of $33.6 \pm 29.8$ in boys a big eater" and "the mother needed a break"; and $20.7 \pm 22.3$ in girls $(P=.005)$, while there were $14.3 \%$ reported other reasons for it. no differences in the overall sample or between

\section{Figure 2. Distribution of feeding modalities in cases and controls}

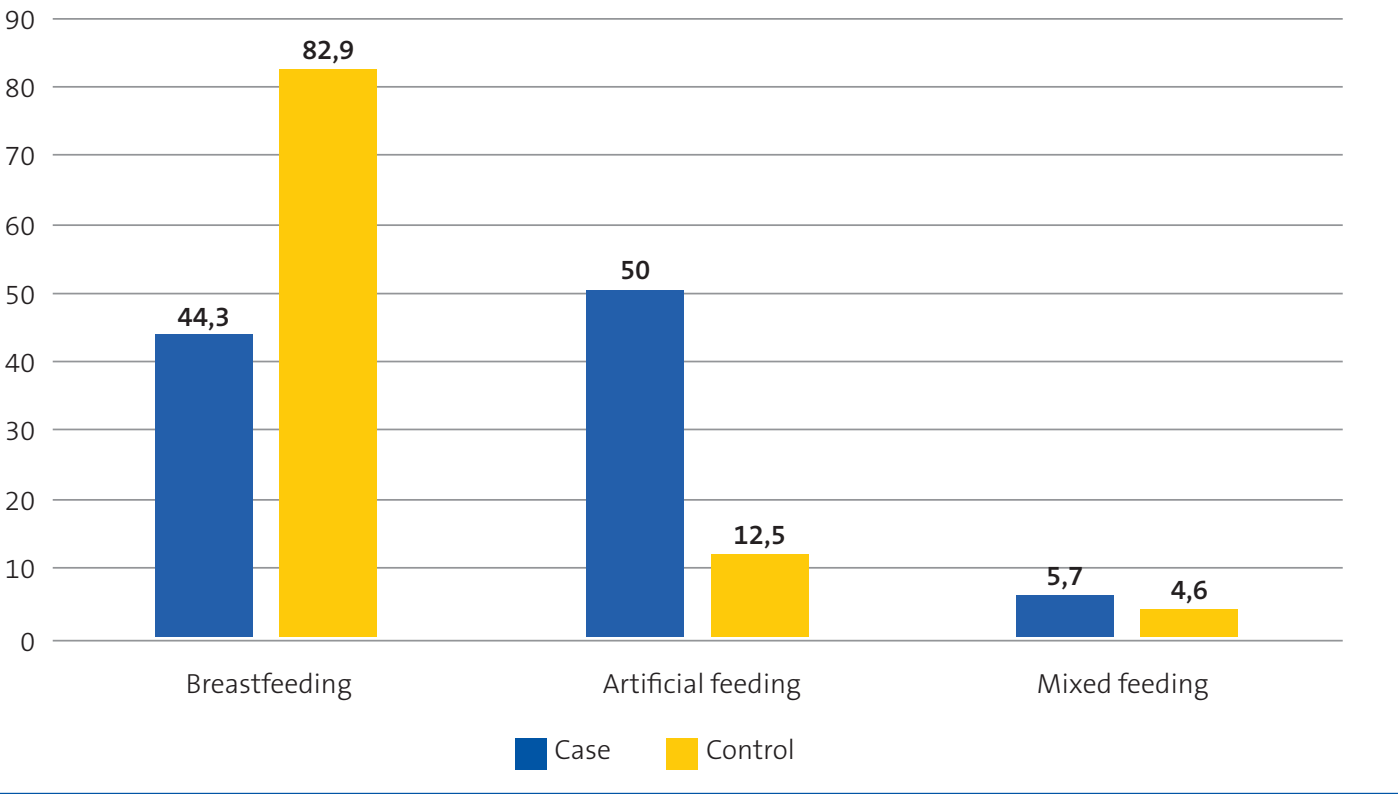


boys and girls with AD based on feeding modality. We did not find statistically significant differences between sexes or by feeding modality in the severity score or in the subjective symptoms (itching and sleep disturbances). When we analysed the intensity of erythema, oedema, crusts, excoriations and lichenification in children diagnosed with AD we found no statistically significant differences based on sex or feeding modality, while the intensity of dryness was higher in males $(P=.049)$.

Table 2 shows the distribution of AD-related clinical features in cases and controls, and their distribution in the sample depending on feeding modality. Itching was more frequent in cases and the onset occurred at an earlier age $(1.0 \pm 1.3$ versus $4.4 \pm 3.1$ years; $P<.001$ ), however, we observed that BF delayed the onset of itching (at $1.9 \pm 2.3$ years for BF versus $1.1 \pm 1.5$ years for $A F ; P<.016$ ) and had a protective effect against developing it (OR, 0.50; 95\% Cl, 0.27-0.93; $P<.029$ ) after adjusting for age, sex, and dry skin. The most marked impact was the protective effect of BF against the development of dry skin (OR, 0.22; $95 \% \mathrm{Cl}, 0.14-$ $0.36 ; P<.001)$ after adjusting for age and sex, and against some types of pollen allergy or allergic rhinitis (OR, 0.35; 95\% Cl, 0.17-0.73; $P=.005)$ adjusting for age and sex. No significant differences were found in either effect when we segmented the data by BF duration.

When we assessed the family history of skin, respiratory or mixed disorders we observed that a positive history was more frequent in children with $\operatorname{AD}(72.9 \%$ versus $44.6 \% ; P<.001)$ and less frequent in children that were breastfed $(50.5 \%$ versus
$64.8 \% ; P=.007)$. When we calculated the risk of AD based on the family history the raw analysis showed an OR of $3.3(95 \% \mathrm{Cl}, 2,1-5,2 ; P<.001)$ and the analysis adjusted for age, sex and feeding modality showed an OR of $3.2(95 \% \mathrm{Cl}, 1.9-5.2$; $P<.001)$.

The mean score of the ICVDAI quality of life questionnaire was $1.1 \pm 2.6$ points overall, and it was $0.85 \pm 1.9$ points in girls and $1.27 \pm 3.0$ points in boys ( $P=.105)$. Table 3 shows the changes found in the items of the ICVDAI and Table 4 the mean score in this questionnaire for cases and controls and by feeding modality. We did not find statistically significant differences based on BF duration or the ICVDAI score.

\section{DISCUSSION}

Breastfeeding is currently the preferred feeding modality for infants due to its nutritional, immunological and psychological benefits. ${ }^{7}$ The recommendations of health workers regarding BF have been changing through time, and differences in BF rates have been observed that are based on geographical area, socioeconomic status, level of education, the incorporation of women into the workforce and the increased duration of maternity leave. ${ }^{21-23}$ In Spain, BF rates started recovering in the 1990s following two decades, the 1970s and 1980s, dominated by artificial feeding. ${ }^{23}$ A study that assessed the prevalence of $\mathrm{BF}$ in the past 15 years (1991-2005) found a BF rate of $60.4 \%$ at 30 days that dropped, albeit less markedly than in

Table 2. Distribution of the clinical characteristics associated with AD in cases and controls and by feeding
modality
\begin{tabular}{|l|c|c|c|c|c|c|} 
& Controls (\%) & Cases (\%) & $P$ & BF* (\%) & AF (\%) & P \\
\hline Itching & 8.2 & 88.6 & $<.001$ & 27.0 & 59.0 & $<.001$ \\
\hline Skin fold involvement & 26.1 & 71.8 & $<.001$ & 58.8 & 72.6 & .060 \\
\hline Dry skin & 15.4 & 92.1 & $<.001$ & 32.1 & 67.6 & $<.001$ \\
\hline Pollen allergy/rhinitis & 4.3 & 17.1 & $<.001$ & 6.3 & 15.2 & .006 \\
\hline Food allergy & 5.0 & 16.4 & $<.001$ & 7.6 & 12.4 & .101 \\
\hline Asthma & 38.6 & 42.9 & .230 & 4.3 & 39.0 & .456 \\
\hline
\end{tabular}

*Includes breastfeeding and mixed feeding.

AD: atopic dermatitis; AF: artificial feeding; BF: breastfeeding 


\begin{tabular}{|c|c|c|c|c|c|c|}
\hline ICVDAI Index** & Controls (\%) & Cases (\%) & $P$ & $\mathrm{BF}^{*}(\%)$ & $\mathrm{AF}(\%)$ & $P$ \\
\hline Itching & 4.0 & 50.7 & $<.001$ & 14 & 36.2 & $<.001$ \\
\hline Irritability & 1.4 & 27.9 & $<.001$ & 6.7 & 21.0 & $<.001$ \\
\hline Sleep disturbance & 0.0 & 18.6 & $<.001$ & 3.5 & 14.3 & $<.001$ \\
\hline School absences & 0.0 & 2.8 & .007 & 0.6 & 1.9 & .236 \\
\hline $\begin{array}{l}\text { Discontinuation of sports } \\
\text { activities }\end{array}$ & 0.4 & 2.1 & .110 & 1.0 & 1.0 & .739 \\
\hline $\begin{array}{l}\text { Discontinuation of recreational } \\
\text { activities }\end{array}$ & 0.4 & 2.1 & .039 & 0.3 & 2.9 & .046 \\
\hline Dietary changes & 0.0 & 7.8 & $<.001$ & 1.9 & 4.8 & .390 \\
\hline Object of mockery & 0.0 & 6.4 & $<.001$ & 1.9 & 2.9 & .852 \\
\hline Pharmacological problems & 0.4 & 26.4 & $<.001$ & 6.3 & 17.1 & $<.001$ \\
\hline Financial expenses & 0.0 & 27.9 & $<.001$ & 5.1 & 21.9 & $<.001$ \\
\hline
\end{tabular}

${ }^{*}$ Includes breastfeeding and mixed feeding. ${ }^{* *}$ Changes in quality of life due to skin problems.

AD: atopic dermatitis; AF: artificial feeding; BF: breastfeeding; ICVDAI: Childhood Atopic Dermatitis Quality of Life Index.

past years, to $45.9 \%$ at three months and to $33.3 \%$ at five months, of which the latter rate was triple the one observed in $1991^{24}$ and has increased slightly in subsequent studies. ${ }^{15}$ Our data showed the same trend described by Valbuena Barrasa in 2005, although there was a small increase in the observed frequency of BF that was similar to the one described by J. M. Rius (2014) in a population from the same health area as the one in our study. Due to the great variability in the presentation of $A D$, several working groups have attempted to develop uniform criteria for its diagnosis, among which the most widely accepted have been those proposed by Hanifin and Rajka in 1980. There are several tools used to measure the severity of $A D$, but until a few years ago, no specific instruments existed to assess the impact of the disease in the patients' quality of life. Such an assessment is key to make appropriate use of health resources and evaluate the effectiveness of therapeutic interventions.
The most commonly used tool to measure the severity of $A D$ is the SCORAD index, which takes into account the size and intensity of the lesions, as well as the symptoms of pruritus and sleep disturbances. SCORAD has demonstrated a strong intraand inter-observer correlation, but when subjective parameters are combined the interpretation of the score can be complicated and information on the impact on quality of life may be lost. ${ }^{25,26}$ Due to this lack of information, we chose to use the ICVDAI questionnaire, which assesses quality of life by means of ten items.

The onset of $A D$ usually occurs in the first year of life, and more specifically between two and three months of age, ${ }^{3}$ although in our study we obtained a higher mean age at diagnosis than the one described by these authors, while also finding that onset was earlier in males than in females. Some authors state that the incidence is higher in females (2:1), although during childhood it is higher

\begin{tabular}{|c|c|c|c|c|c|c|}
\hline & \multicolumn{2}{|c|}{ Mean score \pm SD } & \multirow[b]{2}{*}{$P$} & \multicolumn{2}{|c|}{ Mean score \pm SD } & \multirow[b]{2}{*}{$P$} \\
\hline & Control & Case & & $\mathrm{BF}^{*}$ & $\mathrm{AF}$ & \\
\hline Male & $0.1 \pm 0.4$ & $3.7 \pm 4.4$ & $<.001$ & $0.7 \pm 2.3$ & $2.8 \pm 4.1$ & $<.001$ \\
\hline Female & $0.1 \pm 0.5$ & $2.4 \pm 2.7$ & $<.001$ & $0.7 \pm 1.8$ & $1.5 \pm 2.3$ & .013 \\
\hline Total & $0.1 \pm 0.5$ & $3.1 \pm 3.8$ & $<.001$ & $0.7 \pm 2.1$ & $2.3 \pm 3.5$ & $<.001$ \\
\hline
\end{tabular}

"Includes children that received breastfeeding and mixed feeding.

AF: artificial feeding; BF: breastfeeding; ICVDAI: Childhood Atopic Dermatitis Quality of Life Index; SD: standard deviation. 
in males, with no significant differences between ethnicicies. ${ }^{27}$ Still, the ELIHO study did not identify sex as a risk factor for this disorder. ${ }^{28}$

Since a lower risk of AD was reported in breastfed children, ${ }^{8}$ the controversy surrounding the preventive role of BF in the development of allergic diseases is partly due to the immunological complexity of milk, genetic differences, and methodological differences between studies. In our study, we observed a clear protective effect of BF compared to $A F$ against the development of $A D$, as described in other works, but in our study this effect was independent from the duration of BF, as it appeared just with having been breastfed at all, although some studies suggest a protective effect in high-risk children when they have been exclusively breastfed for a minimum of three to four months. ${ }^{7,10,11}$

In our study we observed that over half of the patients with AD had allergic reactions to food, which was consistent with the results of several studies. ${ }^{29-31}$ Still, if we compare our data with those reported by Acevedo-Villafañe (2009), the prevalence of food allergies in children with $A D$ in our population was much lower, which may be due to methodological differences.

The data on the relationship between food allergies and feeding modality is also contradictory. Some authors state that there is no solid proof that the early use of hydrolysed formulas is associated with allergic disorders, ${ }^{11,32}$ yet according to the Cochrane review (2006) the use of hydrolysed infant formulas could lead to a reduction in the incidence of allergy compared to traditional cow's milk. Other studies in children at risk of atopy that were exclusively breastfed for more than four months showed a significant reduction in the incidence of cow's milk allergy and $A D$ in the first four years of life. ${ }^{33}$ In our study, we observed that the risk of having some type of allergy was considerably lower in children that were breastfed, although this was independent of BF duration.

Atopic dermatitis is strongly correlated with allergic diseases such as asthma, rhinitis, and seasonal conjunctivitis. ${ }^{7,34}$ Along these lines, we found some type of pollen allergy or allergic rhinitis three times more often in cases compared to the control group. Therefore, in our study we observed that BF seems to have a protective effect against allergic rhinitis and atopic dermatitis, consistent with the work of other authors. ${ }^{31,34}$

In their analysis of the factor of genetics or a positive family history, several literature reviews have shown that BF for at least three months compared to AF in infants with hereditary atopy is a protective factor against $A D$, but these reviews show a tenuous protective effect in children without a family history of atopic disease. ${ }^{7,10,11,34,35}$ In our study, we found that BF had a stronger protective effect against $A D$ in children with a positive family history, and this effect was stronger than the one reported by Bloch (2002).

Skin diseases significantly impact quality of life, and the repercussions of $A D$ in the quality of life of children vary widely depending on the severity of the disease and its clinical manifestations. ${ }^{6,36}$ Among all the aspects assessed by the ICVDAI questionnaire in this study, we found that patients with $A D$ differed in itching, mood, sleep disturbances, school absences, sports activities, recreational activities, dietary changes, treatment-related problems, economic burden and being subject to mockery. The atopic child is restless, has sleep disturbances, has concentration difficulties that result in poor academic performance, and the events around him or her have an influence, usually negative, on the disease course itself. ${ }^{37}$ Bolstering our observations, García Sicilia (2010) states that "[...] the magnitude and persistence of itching have an unquestionable and strong impact on quality of life. The sensation of having very dry, inelastic skin can cause great discomfort, and when it is located in very visible areas it may generate rejection, affecting relationships and selfesteem and significantly impinging on personality development during childhood". 


\section{LIMITATIONS}

The retrospective collection of data and the type of study design that we used may result in the characteristic biases of this type of data and of casecontrol studies. Since the mixed feeding group was small, it was combined with the BF group in the statistical analyses.

\section{CONFLICTS OF INTEREST}

The authors declare no conflicts of interest in relation to the preparation and publication of this article.

\section{BIBLIOGRAFÍA}

1. Simpson EL, Hanifin JM. Atopic dermatitis. Med Clin N Am. 2006;90:149-67.

2. Fonseca Capdevila E. El niño con dermatitis atópica. Una visión global. Madrid: Loki and Dimas; 2006.

3. Akdis CA, Akdis M, Biber T, Bindslev-Jensen C, Boquniewicz $M$, Eigenmann P. Diagnosis and treatment of atopic dermatitis in children and adults: European Academy of Allergology and Clinical Immunology/American Academy of Allergy, Asthma and Immunology/PRACTALL. Consensus Report. J Allergy Clin Immunol. 2006;118:152-69.

4. Williams HC. Epidemiology of atopic dermatitis. Clin Dermatol. 2000;25:522-9.

5. Zambrano Pérez E, Zambrano Zambrano A. Eccemas en la infancia. En: Muñoz Calvo MT, Hidalgo Vicario MI, Clemente Pollán J. Pediatría extrahospitalaria. Fundamentos clínicos para atención primaria. 4. a edición. Madrid: Ergón; 2008. p. 901-8.

6. Simonsen $A B$, Sommerlund $M$, Deleuran $M$, Mortz CG, Johansen JD. Course of skin symptoms and quality of life in children referred for patch testing-a long-term follow-up study. Acta Derm Venereol. 2015; 95:206-10

7. Comité de nutrition de la Société française de pédiatrie, Turck D, Vidailhet $M$, Bocquet A, Bresson JL, Briend $A$, et al. Breastfeeding: health benefits for child and mother. Arch Pediatr. 2013;20:S29-48.

\section{ABBREVIATIONS}

95\% Cl: 95\% confidence interval $-\mathrm{AD}$ : atopic dermatitis - BF: breastfeeding - ICVDAI: Childhood Atopic Dermatitis Quality of Life Index $\bullet$ OR: odds ratio $\bullet$ SCORAD: Scoring Atopic Dermatitis.

\section{ACKNOWLEDGMENTS}

We want to thank the whole staff of the Alaquás health care centre, and especially the paediatricians and the paediatric nurses.

8. Grulee CG, Sanford HN. The influence of breast and artificial feeding on infantile eczema. J Pediatr. 1936;9:223-5.

9. Bath-Hextall F, Williams H. Eczema (atopic). Clinical Evidence. 2005.

10. Gdalevich M, Mimouni D, David M, Mimouni M. Breastfeeding and the onset of atopic dermatitis in childhood: a systematic review and meta-analysis of prospective studies. J Am Acad Dermatol. 2001;45:520-7.

11. Blattner CM, Murase JE. A practice gap in pediatric dermatology: does breast-feeding prevent the development of infantile atopic dermatitis? J Am Acad Dermatol. 2014;71:405-6.

12. Laubereau B, Brockow I, Zirngibl A, Koletzko S, Gruebl $A$, von Berg A, et al. Effect of breast-feeding on the development of atopic dermatitis during the first 3 years of life: results from the GINI-birth cohort study. J Pediatr 2004;144:602-7.

13. Friedman NJ, Zeiger RS. The role of breast-feeding in the development of allergies and asthma. J Allergy Clin Immunol. 2005;115:1238-48.

14. Morales Suárez-Varela M, García-Marcos Álvarez L, González Díaz C, Arnedo Pena A, Domínguez Aurrecoechea B. Prevalencia de dermatitis atópica y factores nutricionales en niños de 6-7 años. Aten Primaria. 2007;39:355-60.

15. Rius J.M, Ortuño J, Rivas C, Maravall M, Calzado M.A, López A, et al. Factores asociados al abandono precoz de la lactancia materna en una región del este de España. An Pediatr (Barc). 2014;80:6-15. 
16. OMS/UNICEF. Indicators for Assesing Health Facility Practices That Affect Breastfeeding. Ginebra: Organización Mundial de la Salud; 1993.

17. Hanifin JM, Rajka G. Diagnostic features of atopic eczema. Acta Dermatovenereol Suppl (Stockh). 1980; 92:44-7.

18. Costa C, Rilliet A, Nicolet M, Saurat JH. Scoring atopic dermatitis: the simpler the better? Acta Derm Venereol. 1989;69:41-5.

19. Consenso Nacional de Dermatitis Atópica. En: Sociedad Argentina de Dermatología (SAD) [en línea] [consultado el 12/06/2015]. Disponible en www.der matolarg.org.ar/index.php/dermatolarg/article/ viewFile/379/189

20. García-Díez A, Puig L, Ortiz J, Blanco A. Validity of a telephone survey for determining the prevalence of atopic dermatitis and its seasonal variation in Spain. Actas Dermosifiliogr. 2009;100:298-306.

21. Yaque $M$, Castillo $E$, Praena $M$, Sancho $C$, Fernández A, Herrera $C$, et al. Factores relacionados con el inicio de la lactancia materna en nuestro medio. Rev Pediatr Aten Primaria. 2000;5:35-46.

22. Sacristán Martín AM, Lozano Alonso JE, Gil Costa M, Vega Alonso AT. Situación actual y factores que condicionan la lactancia materna en Castilla y León. Rev Pediatr Aten Primaria. 2011;13:33-46.

23. Colodro-Conde L, Sánchez-Romera JF, Tornero-Gómez MJ, Pérez-Riquelme F, Polo-Tomás M, Ordoñana JR. Relationship between level of education and breastfeeding duration depends on social context: breastfeeding treneds over a 40-year period in Spain. J Hum Lact. 2011;27:272-8.

24. Valbuena Barrasa L, de Lucas Veguillas A, Coca Méndez R, Paciencia de la Fuente C, Madroñal López P, Hernández Fernández E. Evolución de la lactancia materna y de algunos de sus factores condicionantes en nuestro medio. Talavera de la Reina; 2005.

25. Kunz B, Oranje AP, Labrèze L, Stalder JF, Ring J, Taïeb A. Clinical validation and guidelines for the SCORAD index: Consensus Report of the European Task Force on Atopic Dermatitis. Dermatology. 1997;195:10-9.

26. Charman CR, Venn AJ, Williams HC. The patientoriented eczema measure: development and initial validation of a new tool for measuring atopic eczema severity from the patients' perspective. Arch Dermatol. 2004;140:1513-9.
27. Méndez-Cabeza Velázquez J, Alache Zúñiga $H$, Cerrada Cerrada E. Manejo de la dermatitis atópica en Atención Primaria. MEDIFAM. 2003;13:75-84.

28. Blanco Q̊A, Díaz Castella JM, Balañá Vilanova M, Valveny Llobet $\mathrm{N}$. Factores de riesgo de dermatitis atópica y su prevalencia en España (estudio ELIHO). An Pediatr (Barc). 2005;63:480-8.

29. Lack G. Clinical practice. Food allergy. N Engl J Med. 2008;359:1252-60.

30. Chafen JJ, Newberry SJ, Riedl MA, Bravata DM, Maglione $M$, Suttorp MJ, et al. Diagnosing and managing common food allergies: a systematic review. JAMA. 2010;303:1848-56.

31. Acevedo Villafañe C, Latorre Latorre F, Cifuentes Cifuentes L, Díaz-Martínez LA, Garza Acosta O. Influencia de la lactancia materna y la alimentación en el desarrollo de alergias en los niños. Aten Primaria. 2009;41:675-80

32. Osborn DA, Sinn J. Fórmulas que contienen proteínas hidrolizadas para la prevención de alergias y de la intolerancia alimentaria en lactantes (Revisión Cochrane traducida). En: La Biblioteca Cochrane Plus, 2008 Número 4. Oxford: Update Software Ltd. Disponible en: http://www.bibliotecacochrane.com. (Traducida de The Cochrane Library, 2008 Issue 3. Chichester, UK: John Wiley \& Sons, Ltd.).

33. Halken S, Hansen KS, Jacobsen HP, Estmann A, Faelling AE, Hansen LG, et al. Comparison of a partially hydrolyzed infant formula with two extensively hydrolyzed formulas for allergy prevention: a prospective, randomized study. Pediatr Allergy Immunol. 2000;11:149-61.

34. Kramer MS. Breastfeeding and allergy: the evidence. Ann Nutr Metab. 2011;59:20-6.

35. Bloch AM, Mimouni D, Mimouni M, Gdalevich $M$. Does breastfeeding protect against allergic rhinitis during childhood? A meta-analysis of prospective studies. Acta Paediatr. 2002;91:275-9.

36. Lio PA, Lee M, LeBovidge J, Timmons KG, Schneider L. Clinical management of atopic dermatitis: practical highlights and updates from the atopic dermatitis practice parameter 2012. J Allergy Clin Immunol Pract. 2014;2:361-9.

37. Moreno Giménez JC. Dermatitis atópica (revisión). Alergol Inmunol Clin. 2000;15:279-95. 